\title{
Sintering, microstructure, and mechanical properties of PM manganese-molybdenum steels
}

\author{
M. Youseffi, S. C. Mitchell, A. S. Wronski, and A. Cias
}

\begin{abstract}
The effects of $0.5 \mathrm{wt}-\%$ Mo addition on the processing, microstructure, and strength of PM Fe-3.5Mn-0.7C steel are described. Water atomised and sponge irons, Astaloy $1 \cdot 5 \mathrm{Mo}$, milled ferromanganese, and graphite were the starting powders. During sintering in $75 \mathrm{H}_{2} / 25 \mathrm{~N}_{2}$ or pure hydrogen the dewpoint was controlled and monitored; in particular the effects of improving it from -35 to $-60^{\circ} \mathrm{C}$ were investigated. Faster heating rates $\left(\geqslant 20 \mathrm{~K} \mathrm{~min}^{-1}\right)$, sufficient gas flowrates, milling the ferro alloy under nitrogen, a low dewpoint $\left(<-60^{\circ} \mathrm{C}\right)$, and a getter powder can all contribute to the reduction or prevention of oxidation of the manganese, in particular formation of oxide networks in the sintered steels. For $600 \mathrm{MPa}$ compaction pressure densities up to $7 \cdot 1 \mathrm{~g} \mathrm{~cm}^{-3}$ were obtained; these were not significantly affected by sintering at temperatures up to $1180^{\circ} \mathrm{C}$. The sintered microstructures were sensitively dependent on the cooling rate. Irrespective of the presence of Mo, slow furnace cooling at $\sim 4 \mathrm{~K} \mathrm{~min}^{-1}$ resulted in mainly pearlitic structures with some ferrite and coarse bainite, whereas fast cooling at $\sim 40 \mathrm{~K} \mathrm{~min}^{-1}$ produced martensite and some retained austenite, very fine pearlite, bainite, and some ferrite. Young's modulus, determined by tensile and ultrasonic tests, was in the range $110-155 \mathrm{GPa}$. Sintering with $-60^{\circ} \mathrm{C}$ dewpoint resulted in tensile and transverse rupture strengths of 420 and $860 \mathrm{MPa}$ for the $\mathrm{Mn}$ steel, rising to 530 and $1130 \mathrm{MPa}$ as a result of the Mo addition. This contrasts with strength decreases observed when processing included use of high oxygen containing ferromanganese and sintering with $-35^{\circ} \mathrm{C}$ dewpoint.

$\mathrm{PM} / 0811$
\end{abstract}

Dr Youseffi, Mr Mitchell, and Professor Wronski are with the Department of Mechanical and Medical Engineering, University of Bradford, Bradford BD7 1DP, UK and Dr Cias is with the Academy of Mining and Metallurgy, Kraków, Poland. Manuscript received 27 August 1998; accepted 6 April 2000.

(C) 2000 IoM Communications Ltd.

\section{INTRODUCTION}

To improve mechanical properties and hardenability, addition of alloying elements such as nickel, copper, and molybdenum to sintered steels has been practiced for many years, as in wrought steels. These elements do not oxidise readily and special care against oxidation is not required during sintering, which means a poor dewpoint can be tolerated. It would be advantageous, however, in developing PM steels to use elements which impart the best strengthening properties, as contained in wrought steels, and to avoid the carcinogenic and allergenic nickel and non-recyclable copper, not only for economic, but also for legislative reasons. ${ }^{1}$ Some Stackpole alloys ${ }^{2-4}$ thus contain manganese, in place of, or in addition to, the more traditional PM alloying elements. Research into higher Mn additions ${ }^{5-11}$ has not yet lead to commercial exploitation, primarily owing to the problem of formation of manganese oxide networks during the sintering cycle when conventional PM processing technology, with dewpoints no better than $-25^{\circ} \mathrm{C}$, is employed. Cias and co-workers ${ }^{12-14}$ overcame this problem in laboratory and pilot scale ${ }^{13}$ processing and went on to investigate the sinterability and properties of $\mathrm{Fe}-\mathrm{Mn}-\mathrm{C}$ steels, also alloyed further with $\mathrm{Cr}$, Mo, and $\mathrm{Si}^{15}$ The influence of Mo alone appeared unpromising ${ }^{16}$ and accordingly this paper deals with the problem of successful processing of $\mathrm{Fe}-\mathrm{Mn}-\mathrm{Mo}-\mathrm{C}$ alloys.

\section{EXPERIMENTAL PROCEDURES}

Similar experiments were carried at AGH, Kraków, and the University of Bradford (UOB). The main differences were in these procedures: milling the ferromanganese under nitrogen (only at UOB); use of double cone blender at $\mathrm{AGH}$ and turbola mixer at $\mathrm{UOB}$; use of zinc stearate for die wall lubrication (only at $\mathrm{AGH}$ ); addition of liquid paraffin for plasticisation, lubrication, and reduction in segregation of the added powders, particularly graphite (only at $\mathrm{UOB}$ ); sintering in pure hydrogen with $-35^{\circ} \mathrm{C}$ dewpoint at $\mathrm{AGH}$ and in $75 \mathrm{H}_{2} / 25 \mathrm{~N}_{2}$ with $-60^{\circ} \mathrm{C}$ dewpoint at UOB.

\section{Raw materials}

The starting materials were:

- Höganäs water atomised high compressibility iron powder ASC 100.29, some sieved to $<125 \mu \mathrm{m}$,

- Höganäs sponge iron powder NC $100 \cdot 24$,

- Höganäs Astaloy Mo: Fe- $1 \cdot 5 \% \mathrm{Mo}$, some sieved to $<125 \mu \mathrm{m}$,

- HPII ferromanganese containing $73 \% \mathrm{Mn}, \quad 6 \cdot 3 \% \mathrm{C}$, $0.7 \% \mathrm{Si}$, and $1.3 \% \mathrm{O}$, milled and sieved to $<40 \mu \mathrm{m}$,

- Elkem ferromanganese with $77 \% \mathrm{Mn}, 1.3 \% \mathrm{C}, 0.4 \% \mathrm{Si}$, and $0 \cdot 2 \% \mathrm{O}$ milled under nitrogen and sieved to $<53 \mu \mathrm{m}$,

- graphite of $99 \cdot 5 \%$ purity.

\section{Mixing}

Powder mixtures were based on the reference material, $\mathrm{Fe}-3.5 \mathrm{Mn}-0.7 \% \mathrm{C}$ and the standard addition of $0.5 \% \mathrm{Mo}$, accomplished by mixing Astaloy $1.5 \mathrm{Mo}$ with the iron powder. Mn was varied between 3 and $4 \%$ and $\mathrm{C}$ between 0.6 and $0.8 \%$.

\section{Compaction and sintering}

Standard dogbone tensile bars (according to ISO $2740 /$ MPIF standard 10), squared samples of size $15 \times 15 \times 4 \mathrm{~mm}$ and rectangular test specimens, $56 \times 11 \times 5 \mathrm{~mm}$, were compacted for the investigation at 
pressures of 300, 400, 500, 550, and, generally, $600 \mathrm{MPa}$. Some UOB samples were sintered in semiclosed containers containing a mixed getter powder. Sintering was carried out in laboratory ceramic and stainless steel tube furnaces at $1120,1140,1150$, and $1180^{\circ} \mathrm{C}$, generally for $1 \mathrm{~h}$ with heating rates of $75(\mathrm{AGH})$ and $20 \mathrm{~K} \mathrm{~min}^{-1}(\mathrm{UOB})$. Cooling rates of $\sim 4,20$, and $35 \mathrm{~K} \mathrm{~min}^{-1}$ were employed.

At UOB, an inlet dewpoint of $-62^{\circ} \mathrm{C}$ was obtained with a gas flow of $\sim 0.2 \mathrm{~cm}^{3} \mathrm{~min}^{-1} \mathrm{~cm}^{-2}$ of tube cross-sectional area. In order to reduce the moisture content (improve the dewpoint) the furnace was flushed with pure nitrogen for 30 min before the sintering process.

The compositions of the various batches investigated are given in Table 1. Alloys $\mathrm{B}-\mathrm{H}$, were prepared by mixing water atomised Astaloy Mo (Fe-1.5\% Mo) with $\mathrm{NC} 100 \cdot 24$ sponge iron powder and the coarser high oxygen ferromanganese. These were sintered in an $\mathrm{H}_{2} / \mathrm{N}_{2}$ atmosphere initially at $\mathrm{AGH}$ at $-35^{\circ} \mathrm{C}$ dewpoint (alloys $\mathrm{B}-\mathrm{E}$ only). In order to consider the effects of dewpoint and sintering temperature, compacts prepared at $\mathrm{AGH}$ were sintered at UOB in $\mathrm{H}_{2} / \mathrm{N}_{2}$ atmosphere of $<-60^{\circ} \mathrm{C}$ dewpoint at temperatures of $1120^{\circ} \mathrm{C}$ (alloy $\mathrm{F}$ ), $1150^{\circ} \mathrm{C}$ (alloy G), and $1180^{\circ} \mathrm{C}$ (alloy $\mathrm{H}$ ). Later experiments at UOB involved alloys A and I which utilised fine, low oxygen content ferromanganese and sieved ASC100.29 and Astaloy Mo to remove the coarser fractions and ensure better homogeneity of manganese in these particles. Liquid paraffin was used as the binder, dewpoint was maintained at $-60^{\circ} \mathrm{C}$ and a slightly higher sintering temperature $\left(1140^{\circ} \mathrm{C}\right)$ and a getter were employed.

\section{Differential thermal analysis}

The DTA studies were carried out on a Stanton DTA thermal balance, using carbonyl nickel powder compact as the reference/neutral sample and alumina crucibles. Experiments were conducted on both the low and high carbon ferromanganese powder compacts under pure hydrogen from room temperature up to $1200^{\circ} \mathrm{C}$ at heating and cooling rates of $10 \mathrm{~K} \mathrm{~min}^{-1}$.

\section{Dilatometry}

A Netzch 402E dilatometer interfaced to a computer through a data acquisition program was used to study alloy compacts. Experiments were conducted in an alumina tube under hydrogen, dewpoint $-35^{\circ} \mathrm{C}$, with a $1 \mathrm{~h}$ hold at $1120^{\circ} \mathrm{C}$ and heating and cooling rates of $10 \mathrm{~K} \mathrm{~min}^{-1}$. Evaporation of $\mathrm{Mn}$ resulted in 1-3\% loss in weight.

\section{Mechanical testing}

Specimens were tested in tension or simple bending at a cross-head speed of $0.5 \mathrm{~mm} \mathrm{~min}^{-1}$. Additionally for batches A and I the Young's modulus was determined by extensometric (specimens $25 \mathrm{~mm}$ in length strained at an extension rate of $\left.0 \cdot 1 \mathrm{~mm} \mathrm{~min}^{-1}\right)$ and ultrasonic techniques.

\section{RESULTS \\ DTA}

The heating and cooling curves showed a very similar trend for both powder compacts. Of note was an indication of an endothermic peak, with no corresponding exothermic peak on cooling at $1070^{\circ} \mathrm{C}$. It is to be associated with the appearance of a previously reported ${ }^{9,10}$ transient liquid phase. Absence of the exotherm can be interpreted as being owing to $\mathrm{Mn}$ diffusion and evaporation. It should be mentioned that the ternary isothermal section of the $\mathrm{Fe}-\mathrm{Mn}-\mathrm{C}$ phase diagram ${ }^{17,18}$ contains two different types of carbide $\left(\mathrm{M}_{3} \mathrm{C}\right.$ and $\left.\mathrm{M}_{23} \mathrm{C}_{6}\right)$ at $1000^{\circ} \mathrm{C}$, which transform to $\mathrm{M}_{3} \mathrm{C}+$ liquid at $1100^{\circ} \mathrm{C}$. The DTA results suggest that liquid phase formation resulting from melting of ferromanganese at $\sim 1070^{\circ} \mathrm{C}$ could be a possible densification mechanism during sintering.

\section{Dilatometry}

Traces for $\mathrm{Fe}-0.5 \mathrm{Mo}-3 \mathrm{Mn}-0.6 \mathrm{C}, \mathrm{Fe}-0.5 \mathrm{Mo}-4 \mathrm{Mn}-0 \cdot 6 \mathrm{C}$, and $\mathrm{Fe}-0.5 \mathrm{Mo}-3 \mathrm{Mn}-0 \cdot 8 \mathrm{C}$ samples, pressed at $500 \mathrm{MPa}$ to give green densities in the range $6.5-6.8 \mathrm{gm} \mathrm{cm}^{-3}$, are presented in Fig. 1. The expected depression of the $\alpha / \gamma$ transformation is to be noted, as is the absence of a definite indication of liquid phase formation. It would therefore appear that $\mathrm{Mn}$ diffusion into $\mathrm{Fe}$ and $\mathrm{Fe}-\mathrm{Mo}$ powder particles below $1070^{\circ} \mathrm{C}$ prevents any significant amount of liquid forming up to $1120^{\circ} \mathrm{C}$. The $0 \cdot 3-0 \cdot 5 \%$ linear contractions at the sintering temperature are ascribed to limited densification characteristic of specimens compacted at low pressures. The overall linear changes after the sintering cycle were within $\pm 0.5 \%$, indicating promise of dimensional stability at conventional sintering temperatures for this alloy system.

Table 1 Compositional and sintering parameters of alloys formulated by additions of ferromanganese and graphite to iron and Astaloy powders compacted at $600 \mathrm{MPa}$

\begin{tabular}{|c|c|c|c|c|c|}
\hline Alloy & $\begin{array}{l}\text { Nominal } \\
\text { composition }\end{array}$ & Formulation & $\begin{array}{l}\text { Sintering } \\
\text { atmosphere/ } \\
\text { dewpoint }\end{array}$ & $\begin{array}{l}\text { Sintering } \\
\text { temperature, } \\
{ }^{\circ} \mathrm{C}\end{array}$ & $\begin{array}{l}\text { Sintered } \\
\text { density, } \\
\mathrm{g} \mathrm{cm}^{-3}\end{array}$ \\
\hline A & $\mathrm{Fe}-3 \cdot 5 \mathrm{Mn}-0 \cdot 7 \mathrm{C}$ & $\begin{array}{l}\text { Sieved ASC } 100 \cdot 29+\text { sieved Elkem ferromanganese } \\
\text { + graphite + liquid paraffin }\end{array}$ & $\begin{array}{l}75 \mathrm{H}_{2} / 25 \mathrm{~N}_{2} \\
-60^{\circ} \mathrm{C}\end{array}$ & 1140 & $7 \cdot 0$ \\
\hline B & $\mathrm{Fe}-3 \mathrm{Mn}-0.5 \mathrm{Mo}-0 \cdot 6 \mathrm{C}$ & $\begin{array}{l}\text { NC } 100 \cdot 24+\text { Astaloy } 1 \cdot 5 \mathrm{Mo}+\mathrm{HP} \text { ferromanganese + graphite } \\
+ \text { zinc stearate }\end{array}$ & $\begin{array}{l}\mathrm{H}_{2} \\
-35^{\circ} \mathrm{C}\end{array}$ & 1120 & $6 \cdot 8$ \\
\hline $\mathrm{C}$ & $\mathrm{Fe}-3 \mathrm{Mn}-0.5 \mathrm{Mo}-0 \cdot 8 \mathrm{C}$ & $\begin{array}{l}\text { NC100 } 24+\text { Astaloy } 1 \cdot 5 \mathrm{Mo}+\mathrm{HP} \text { ferromanganese }+ \text { graphite } \\
+ \text { zinc stearate }\end{array}$ & $\begin{array}{l}\mathrm{H}_{2} \\
-35^{\circ} \mathrm{C}\end{array}$ & 1120 & $6 \cdot 8$ \\
\hline $\mathrm{D}$ & $\mathrm{Fe}-4 \mathrm{Mn}-0.5 \mathrm{Mo}-0 \cdot 6 \mathrm{C}$ & $\begin{array}{l}\text { NC100 } 24+\text { Astaloy } 1 \cdot 5 \mathrm{Mo}+\mathrm{HP} \text { ferromanganese }+ \text { graphite } \\
+ \text { zinc stearate }\end{array}$ & $\begin{array}{l}\mathrm{H}_{2} \\
-35^{\circ} \mathrm{C}\end{array}$ & 1120 & $6 \cdot 7$ \\
\hline $\mathrm{E}$ & $\mathrm{Fe}-4 \mathrm{Mn}-0.5 \mathrm{Mo}-0 \cdot 8 \mathrm{C}$ & $\begin{array}{l}\text { NC100 } 24+\text { Astaloy } 1 \cdot 5 \mathrm{Mo}+\mathrm{HP} \text { ferromanganese }+ \text { graphite } \\
+ \text { zinc stearate }\end{array}$ & $\begin{array}{l}\mathrm{H}_{2} \\
-35^{\circ} \mathrm{C}\end{array}$ & 1120 & $6 \cdot 7$ \\
\hline $\mathrm{F}$ & $\mathrm{Fe}-3 \mathrm{Mn}-0.5 \mathrm{Mo}-0 \cdot 8 \mathrm{C}$ & $\begin{array}{l}\text { NC100. } 24+\text { Astaloy } 1 \cdot 5 \mathrm{Mo}+\mathrm{HP} \text { ferromanganese + graphite } \\
+ \text { zinc stearate }\end{array}$ & $\begin{array}{l}75 \mathrm{H}_{2} / 25 \mathrm{~N}_{2} \\
-60^{\circ} \mathrm{C}\end{array}$ & 1120 & $6 \cdot 8$ \\
\hline $\mathrm{G}$ & $\mathrm{Fe}-3 \mathrm{Mn}-0.5 \mathrm{Mo}-0 \cdot 8 \mathrm{C}$ & $\begin{array}{l}\text { NC100 } 24+\text { Astaloy } 1 \cdot 5 \mathrm{Mo}+\mathrm{HP} \text { ferromanganese }+ \text { graphite } \\
+ \text { zinc stearate }\end{array}$ & $\begin{array}{l}75 \mathrm{H}_{2} / 25 \mathrm{~N}_{2} \\
-60^{\circ} \mathrm{C}\end{array}$ & 1150 & $6 \cdot 6$ \\
\hline $\mathrm{H}$ & $\mathrm{Fe}-3 \mathrm{Mn}-0.5 \mathrm{Mo}-0 \cdot 8 \mathrm{C}$ & $\begin{array}{l}\text { NC100 } 24+\text { Astaloy } 1 \cdot 5 \mathrm{Mo}+\mathrm{HP} \text { ferro manganese }+ \text { graphite } \\
+ \text { zinc stearate }\end{array}$ & $\begin{array}{l}75 \mathrm{H}_{2} / 25 \mathrm{~N}_{2} \\
-60^{\circ} \mathrm{C}\end{array}$ & 1180 & $6 \cdot 7$ \\
\hline I & $\mathrm{Fe}-3 \cdot 5 \mathrm{Mn}-0.5 \mathrm{Mo}-0 \cdot 7 \mathrm{C}$ & $\begin{array}{l}\text { Sieved ASC } 100 \cdot 29+\text { sieved staloy } 1 \cdot 5 \mathrm{Mo}+\text { sieved Elkem } \\
\text { ferromanganese }+ \text { graphite + liquid paraffin }\end{array}$ & $\begin{array}{l}75 \mathrm{H}_{2} / 25 \mathrm{~N}_{2} \\
-60^{\circ} \mathrm{C}\end{array}$ & 1140 & $7 \cdot 1$ \\
\hline
\end{tabular}




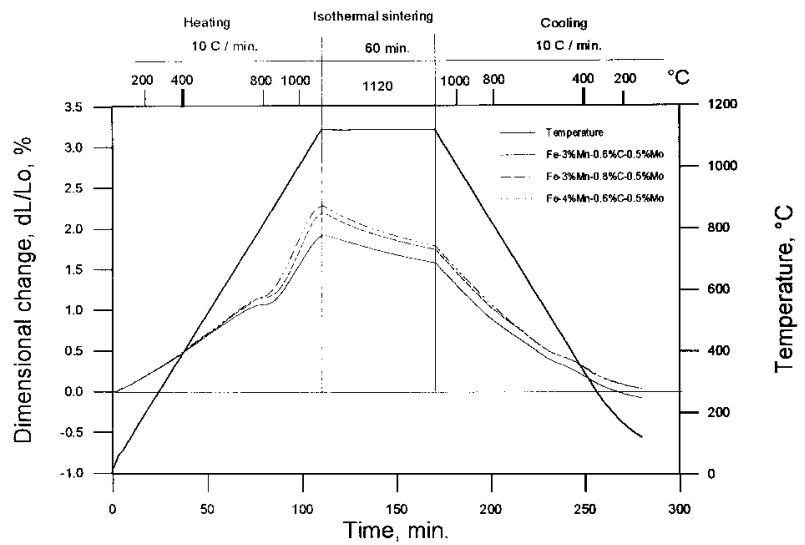

$a \mathrm{Fe}-0 \cdot 5 \mathrm{Mo}-3 \mathrm{Mn}-0 \cdot 6 \mathrm{C} ; \quad b \quad \mathrm{Fe}-0.5 \mathrm{Mo}-4 \mathrm{Mn}-0 \cdot 6 \mathrm{C} ; \quad c \quad \mathrm{Fe}-$ $0 \cdot 5 \mathrm{Mo}-3 \mathrm{Mn}-0 \cdot 8 \mathrm{C}$

1 Dilatometric traces for samples involving a 60 minute hold at $1120^{\circ} \mathrm{C}$

\section{Processing characteristics}

Green densities of tensile and bend specimens were in the range $6 \cdot 7-7 \cdot 1 \mathrm{~g} \mathrm{~cm}^{-3}$; higher values being favoured by sieving to finer fractions the water atomised Astaloy Mo and iron powders, lower Mn contents and use of liquid paraffin. The sintering parameters for the various batches investigated are recorded in Table 1. Significant dimensional changes were not detected upon sintering, consistent with the dilatometric data. There was usually up to $0 \cdot 1-0 \cdot 2 \% \mathrm{C}$ and, depending on the sintering temperature and atmosphere, up to $0 \cdot 3 \%$. Magnesium loss during the sintering cycles, as evidenced by the post-sintering chemical analyses, two examples of which are presented in Table 2.

\section{Sintered microstructures}

Most of the sintered specimens had heterogeneous microstructures with hardness increasing with higher alloying contents. Microhardness values (HV0.025) reported now refer to the steels containing $3 \cdot 5 \% \mathrm{Mn}$ (alloys $\mathrm{A}$ and I). The microstructures of slowly cooled specimens consisted of pearlite of $190-210 \mu \mathrm{HV}$, some coarse bainite of $\sim 320 \mathrm{HV} 0.025$ and $\sim 10 \%$ pores. Some martensite of $\sim 760 \mathrm{HV0} 025$ and retained austenite were also observed, particularly in the areas with high manganese concentration (owing to its heterogeneous distribution). Similar microstructures were observed for the faster cooled specimens, except that the pearlite (troostite) and bainite were finer, with higher microhardness values of $\sim 250$ and 390 HV0.025, respectively. Martensite HV0.025 ranged up to 1110 .

The effects of finer powders, lower dewpoint, use of getter and increasing sintering temperature were beneficial in eliminating the oxide networks and decreasing inhomogeneity (shorter diffusion paths for finer particles and no oxide barriers). The combined use of liquid paraffin and finer powders increased the relative density to above 7.0. Illustrated in Figs. $2-5$ is the effect of dewpoint $(-35$ and $\left.-60^{\circ} \mathrm{C}\right)$ and sintering temperature $\left(1120,1140\right.$, and $\left.1180^{\circ} \mathrm{C}\right)$

Table 2 Chemical analysis ( $\%$ by weight) of sintered Mn steels

\begin{tabular}{llllll}
\hline & \multicolumn{6}{c}{ Starting powder mixture, \% } \\
\cline { 2 - 6 } & Mn & C & Mo & O & Fe \\
\hline $\mathrm{Fe}-3 \cdot 5 \mathrm{Mn}-0 \cdot 7 \mathrm{C}$ & $3 \cdot 14$ & 0.60 & $\ldots$ & 0.58 & Bal. \\
$\mathrm{Fe}-3 \cdot 5 \mathrm{Mn}-0 \cdot 7 \mathrm{C}-0 \cdot 5 \mathrm{Mo}$ & $3 \cdot 20$ & 0.63 & 0.47 & 0.49 & Bal. \\
\hline
\end{tabular}

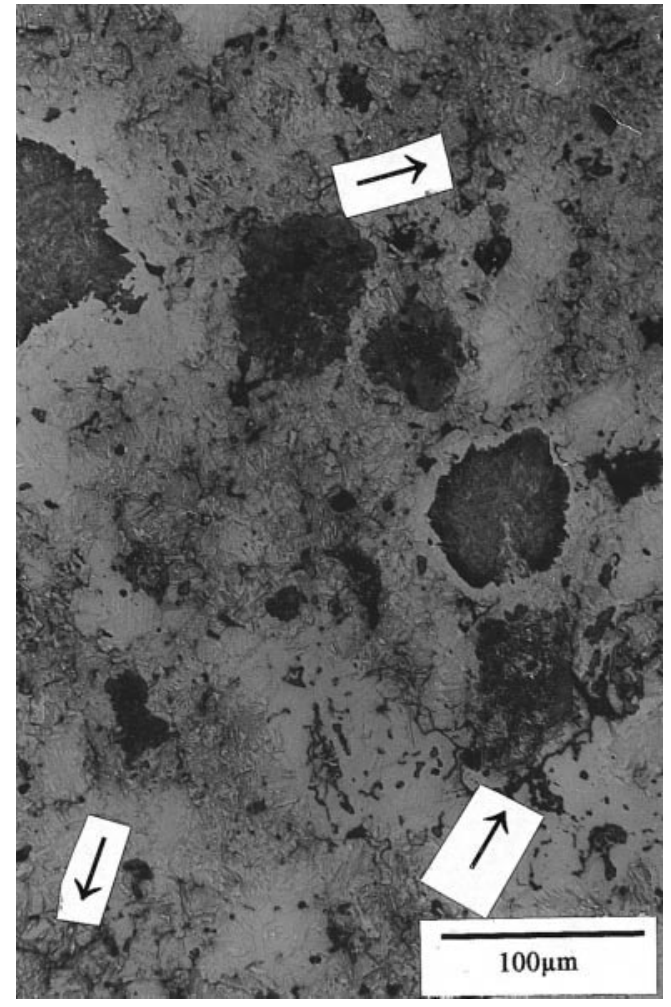

2 Optical micrograph of $\mathrm{Fe}-0 \cdot 5 \mathrm{Mo}-3 \mathrm{Mn}-0 \cdot 8 \mathrm{C}$ sintered at $1120^{\circ} \mathrm{C}$ with dewpoint of $-35^{\circ} \mathrm{C}$ : note heterogeneous microstructure owing to poor diffusion and notable presence of oxide networks (arrowed)

on the microstructures of slowly cooled specimens. To be noted in Fig. 2 (poor dewpoint, low sintering temperature) is the pronounced presence of the oxide networks. Their occurrence is reduced if the dewpoint is improved to $-60^{\circ} \mathrm{C}$ (Fig. 3) but only the combination of $1180^{\circ} \mathrm{C}$ and the better dewpoint succeeds in eliminating these undesirable microstructural features (Fig. 4). Their absence facilitates good particle bonding, more homogeneous alloying, better solid state and grain boundary diffusion, and accordingly potentially higher densities for higher sintering temperatures. Thus for specimens processed with the finer (sieved) base powder and when liquid paraffin was the binder/lubricant there was even less segregation and increasing uniformity of distribution of the phases (Fig. 5) except for some areas of martensite and retained austenite. These microstructural observations are consistent with recent published work on $\mathrm{Fe}-\mathrm{Mn}-\mathrm{Mo}-\mathrm{Cr}-\mathrm{Si}-\mathrm{C}$ alloys ${ }^{12-15}$ which draws attention to microstructural heterogeneity and the need of appropriate local sintering atmosphere if oxidation is to be avoided.

\section{Mechanical properties}

Young's modulus evaluated by the direct extensometric technique was in the range 110-120 GPa. To compute it using the ultrasonic technique, the following equation

$$
E_{\mathrm{c}}=((1+v)(1-2 v) /(1-v)) \rho\left(V_{\mathrm{c}}\right)^{2}
$$

where $E_{\mathrm{c}}$ is the (compressive) Young's modulus, and $v$, the Poisson's ratio, was employed. For porous materials ${ }^{19}$

$$
v=0.068 \mathrm{e}^{1.372(1-\mathrm{P})}
$$

where $P$ is the volume fraction of porosity (between $0 \cdot 05-0 \cdot 35), \rho$ the density, and $V_{\mathrm{c}}$ the compressive wave velocity. Resultant values for $E$ were in the range 145 $155 \mathrm{GPa}$. The strength data for the various compositions and processing routes, summarised in Table 1, are recorded 


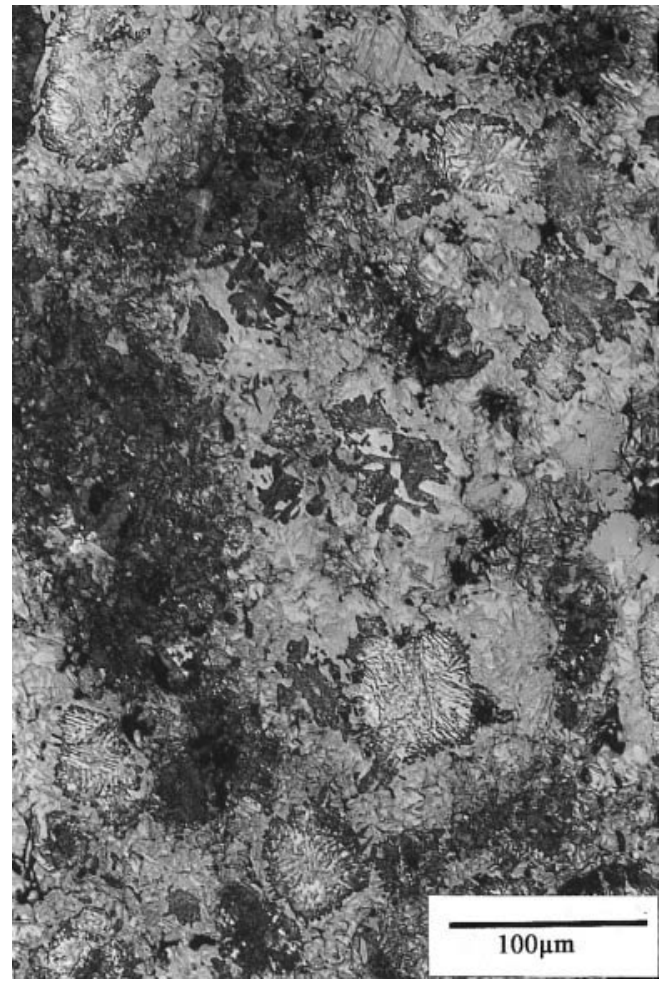

3 Optical micrograph of $\mathrm{Fe}-0 \cdot 5 \mathrm{Mo}-3 \mathrm{Mn}-0 \cdot 8 \mathrm{C}$ sintered at $1120^{\circ} \mathrm{C}$ with dewpoint of $-60^{\circ} \mathrm{C}$ : improved diffusion and much smaller presence of oxides compared with Fig. 2 illustrate the effect of improving the dewpoint from -35 to $-60^{\circ} \mathrm{C}$

in Table 3. In evaluating the transverse rupture strength, the conventional elastic beam 'strength of materials' formula for three-point bending, $\sigma_{\mathrm{f}}=3 L P_{\mathrm{f}} / 2 W D^{2}$ was used.

\section{DISCUSSION}

The apparent discrepancy in the values of the Young's modulus obtained by the two methods employed is related to the porous microstructure of the specimens investigated, resulting in plastic deformation being initiated at different stress levels in different sintering necks. This results in a very limited range of linear stress-strain behaviour. Accordingly extensometric measurements invariably incorporate some non-linear strain; whereas smaller linear strains are sampled ultrasonically ${ }^{20,21}$ The experimental values, $110-120$ and $145-155 \mathrm{GPa}$, respectively, can be compared with the empirical prediction of $\mathrm{McAdam}^{19}$ for sintered porous materials with porosity levels in the range 5-35 vol.- $\%$

$$
E_{\mathrm{s}}=E_{\mathrm{o}}(1-P)^{3 \cdot 4}
$$

where $E_{\mathrm{s}}$ is the Young's modulus of the sintered material

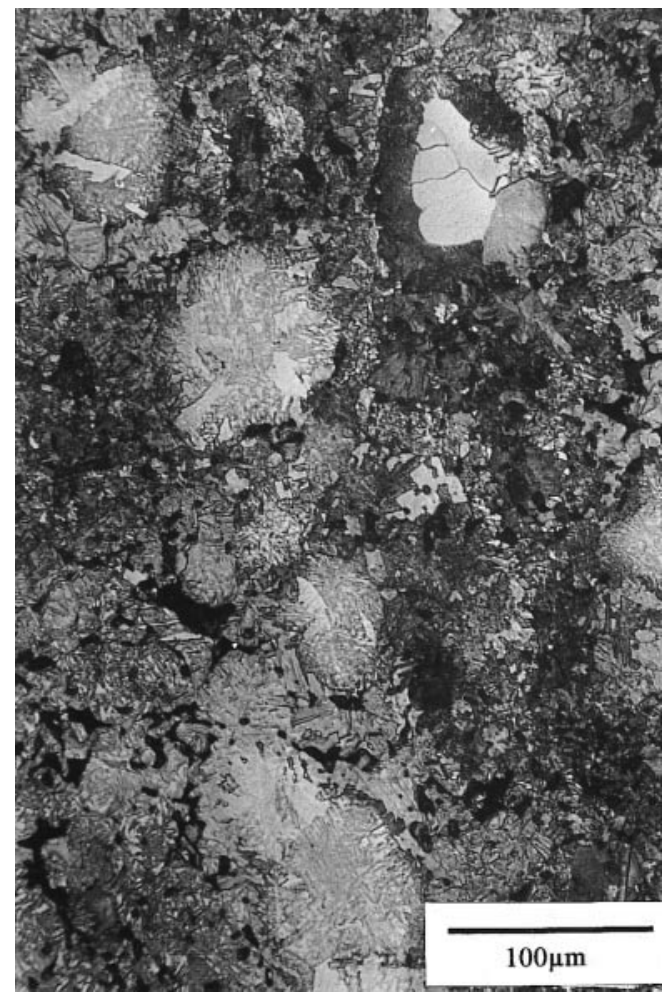

4 Optical micrograph of $\mathrm{Fe}-0 \cdot 5 \mathrm{Mo}-3 \mathrm{Mn}-0 \cdot 8 \mathrm{C}$ sintered at $1180^{\circ} \mathrm{C}$ with dewpoint of $-60^{\circ} \mathrm{C}$ : note improved diffusion and absence of oxides resulting from increasing sintering temperature

at porosity $P$ and $E_{\mathrm{o}}$, the Young's modulus of the fully dense material, which gives $140 \mathrm{GPa}$ for $10 \%$ porosity.

The problem of higher computed values of transverse rupture strength than of tensile strength for the same PM material, especially one possessing some ductility, has been recently analysed for Mn steels. ${ }^{14}$ It was noted that the equation: $\sigma_{\mathrm{f}}=3 L P_{\mathrm{f}} / 2 W D^{2}$, invariably used to calculate the bend strength, is only valid for linearly elastic brittle materials, whereas plastic strains of over $2 \%$ were recorded in some of our tensile tests. Furthermore, in a tensile specimen the whole gauge volume is under the applied tensile stress, whereas in a three point bend test only half of the specimen is under a tensile stress, which reduces to zero at midsection and external loading points from the maximum value computed. According to fracture mechanics, the failure origin is determined by a combination of high stress and large flaw size. In the latter case it is unlikely that the largest flaw will be under the maximum tensile stress, which implies a high probability of higher values of bend than tensile strength being recorded.

The considerable improvement in the mechanical properties (Table3) obtained as a result of sieving and use of

Table 3 Mechanical properties data for as sintered specimens

\begin{tabular}{lllll}
\hline Alloy & Nominal composition & $\begin{array}{l}\text { Transverse rupture } \\
\text { strength, MPa }\end{array}$ & $\begin{array}{l}\text { Tensile strength, } \\
\text { MPa }\end{array}$ & $\begin{array}{l}\text { Failure strain, } \\
\%\end{array}$ \\
\hline A & Fe-3.5Mn-0.7C & 860 & 420 & $1 \cdot 5-2 \cdot 5$ \\
B & Fe-3Mn-0.5Mo-0.6C & 750 & 460 & $>1$ \\
C & Fe-3Mn-0.5Mo-0.8C & 590 & 320 & $>1$ \\
D & Fe-4Mn-0.5Mo-0.6C & 530 & 310 & $>1$ \\
E & Fe-4Mn-0.5Mo-0.8C & 540 & 280 & $>1$ \\
F & Fe-3Mn-0.5Mo-0.8C & 670 & & $>1$ \\
G & Fe-3Mn-0.5Mo-0.8C & 650 & 530 & 1 \\
H & Fe-3Mn-0.5Mo-0.8C & 690 & & $1 \cdot 5-2 \cdot 5$ \\
I & Fe-3.5Mn-0.5Mo-0.7C & 1130 & &
\end{tabular}




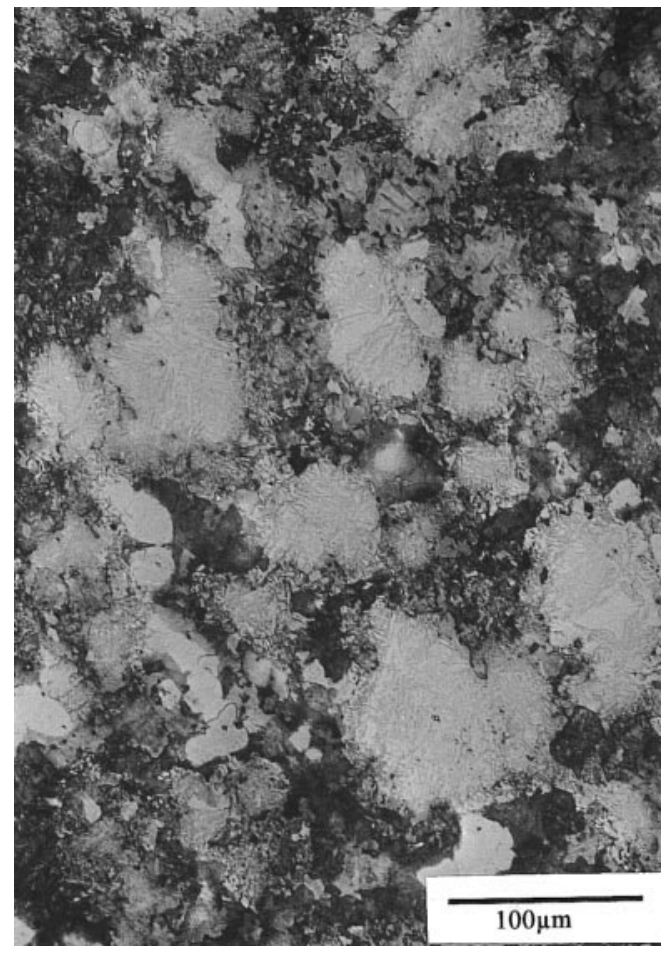

5 Optical micrograph of $\mathrm{Fe}-0 \cdot 5 \mathrm{Mo}-3 \cdot 5 \mathrm{Mn}-0 \cdot 7 \mathrm{C}$ made from sieved water atomised powders sintered at $1140^{\circ} \mathrm{C}$ with dewpoint of $-60^{\circ} \mathrm{C}$ : note the acceptable microstructure free of oxides and with less porosity

liquid paraffin as the binder for the finer powders is to be noted. The improvement owing to the reduced dewpoint and higher sintering temperatures, when slower cooling was also employed, is only of the order of $20 \%$ on the transverse rupture stress. Accordingly it is necessary to consider the detailed compositions of the green compacts and the mechanism of sintering.

Historically the sintering of manganese steels has been performed with little or no consideration of the oxygen content of the starting powders or even the water content of the sintering atmosphere (dewpoint). Different base powders have been used by previous groups of investigators, ranging from eddy milled Hametag iron through air or water atomised iron to chemically reduced sponge iron. The morphology of these are radically different, Hametag iron is leaflike with a thickness of less than $20 \mu \mathrm{m}$, while the atomised powders range from 45 to $150 \mu \mathrm{m}$ in particle size. Sponge iron has a similar particle size to the atomised powders but, because of its internal connected porosity, has a very high specific surface.

During heating the ferromanganese master alloy particles begin to volatilise and produce a cloud of manganese vapour. This vapour will then surround the compacts but will also fill internal pores both between particles and also, in the case of the sponge iron, the internal interconnected porosity of individual particles. This has a beneficial effect in that, owing to oxidation of the manganese vapour by reaction with water vapour in the sintering gas, the atmosphere is effectively dried locally owing to the reaction

$$
\mathrm{Mn}+\mathrm{H}_{2} \mathrm{O}=\mathrm{MnO}+\mathrm{H}_{2}
$$

This will alter locally the ratio of $\mathrm{H}_{2} / \mathrm{H}_{2} \mathrm{O}$ (effective dewpoint) beneficially and allow reduction to take place at a higher overall water content (dewpoint) of the sintering atmosphere than would normally be expected for a given temperature. This is best illustrated by reference to the Ellingham-Richardson diagram for oxidation/reduction of manganese/manganese oxide which shows that reduction of manganese oxide can proceed either by raising the sintering temperature or by lowering the $\mathrm{H}_{2} / \mathrm{H}_{2} \mathrm{O}$ ratio for a given sintering temperature. The manganese oxide thus formed and which remains in the pores has not been found deleterious to mechanical properties.

It is obvious then, that the oxygen content of the starting powders plays a significant role and determines, in conjunction with the atmosphere dewpoint, the lowest temperature at which successful sintering of manganese steels can proceed. That is to say that, the lower the oxygen and water contents the lower the temperature required to promote reducing conditions. If one considers the morphology of the iron powders and notes that, in general, the maximum diffusion distance for manganese into iron at normal sintering temperatures is about $15-20 \mu \mathrm{m}$, then it follows that powders of effective particle size $>40 \mu \mathrm{m}$ cannot be homogenised. This is where both eddy milled and sponge iron powders excel, because the leaflike eddy milled powder is $<40 \mu \mathrm{m}$ at its minimum chord and the internal porosity of the sponge iron powder allows manganese vapour to reach internal surfaces, thus lowering the effective particle size for diffusion.

Previous researchers have stated that for best manganese distribution and mechanical properties, it is best to press compacts to a green density of $<7 \mathrm{~g} \mathrm{~cm}^{-3}$. This has been necessary because the mean particle size of the ferromanganese master alloy addition has been of the order of $45 \mu \mathrm{m}$, with no attempt made to lower the surface oxide of these particles. Homogenisation then takes place purely by manganese vapour transport, but has the deleterious effect of leaving relatively large pores at the sites of the ferromanganese donor particles. Additionally large oxygen content will reduce the effectiveness of the reaction shown in equation (4). If the ferromanganese donor is milled under inert atmosphere to a mean particle size of $<10 \mu \mathrm{m}$, homogenisation is achieved even at higher green densities. This is because the distribution of the particles is changed for a given weight per cent addition of the donor and thus the manganese vapour does not have to travel such large distances. The low oxygen content also plays a significant role in improving the efficiency of the reaction of equation (4). Additionally, the higher green density, coupled with the smaller particle size, leads to a smaller overall pore size after volatilisation and gives an improvement in static strength (Table 3 ) and is expected to improve fatigue resistance for a given density.

Turning now to the effect of incorporating Mo into the $\mathrm{Fe}-\mathrm{Mn}-\mathrm{C}$ alloy, it is to be recalled that samples $\mathrm{B}-\mathrm{H}$ were produced using mixtures of sponge iron, Astaloy $1.5 \% \mathrm{Mo}$, milled high carbon, $1.29 \% \mathrm{O}$ ferromanganese and fine graphite. It was considered that a final molybdenum content of $\sim 0.5 \%$ would be adequate to improve strength and hardenability of the manganese containing alloys. Most microstructures showed problems of poor molybdenum diffusion into the sponge iron and conversely poor manganese diffusion into the Astaloy Mo particles. This gave rise to different transformation products in different areas of the specimens owing to changes in chemical composition and associated hardenability. The samples sintered in the better dewpoint at UOB $(\mathrm{F}-\mathrm{H})$, though of somewhat higher strength and ductility (Table 3 ), still showed some heterogeneity (Fig. 4).

In an effort to improve on the mechanical properties of the manganese alloy using a mix of sponge iron and water atomised Astaloy $1.5 \%$ Mo powders, a new alloy was mixed using sieved water atomised ASC 100.29 and Astaloy $1.5 \%$ Mo powders (I). Despite the lower diffusivity of Mn into 'solid' water atomised powder particles compared with sponge iron, better mechanical properties were obtained. The higher strength alloy consisted of fine, low oxygen content ferromanganese coupled with sieved $(<125 \mu \mathrm{m})$ Astaloy $1.5 \%$ Mo and ASC100.29 water atomised powders 
sintered at $1140^{\circ} \mathrm{C}$ (higher temperatures are to be investigated). These samples were also mixed using liquid paraffin as a plasticiser and binder system, which improved the green density and prevented graphite segregation, a problem noted in previous experiments.

\section{CONCLUSIONS}

This work has shown that, when the oxygen content of the raw materials is minimised (e.g. milling under an inert atmosphere of the ferromanganese alloy), fine powders, sieved to below $\sim 100 \mu \mathrm{m}$, are employed, and the sintering conditions ensure a reducing local atmosphere (e.g. $-60^{\circ} \mathrm{C}$ dewpoint when processing at $\sim 1140^{\circ} \mathrm{C}$ ), it is possible to obtain acceptable microstructures and good mechanical strengths in excess of $500 \mathrm{MPa}$ with $2-3 \%$ ductility in sintered $3 \mathrm{Mn}-0.5 \mathrm{Mo}-0 \cdot 7 \mathrm{C}$ steels, and that the effect of Mo is beneficial. It should be added that further alloy development should also consider $\mathrm{Cr}^{15}$ fine $\mathrm{Si}$, higher sintering temperatures and more precisely the amounts of the alloying elements.

\section{ACKNOWLEDGEMENTS}

The authors wish to acknowledge the contributions of project students, $\mathrm{Mr}$ A. Romanski at $\mathrm{AGH}$ and $\mathrm{Mr} \mathrm{A}$. M. Bhatti at UOB, who carried out the initial experiments. The work reported forms part of a PM structural steels R\&D programme, funded by the European Union in its COPERNICUS programme and by NATO as a Science for Peace project.

\section{REFERENCES}

1. EU Carcinogen Directives 90/394/EC and 91/322/EEC.

2. R. SHIVANATH, P. K. JONES, and R. LAWCOCK: 'Advances in powder metallurgy and particulate meaterials', 13-427; 1996 Princeton, NJ, MPIF.
3. P. K. JONES, K. B. GODER, R. LAWCOCK, and R. SHIVANATH: 'Advances in powder metallurgy and particulate meaterials, 13-439; 1996 Princeton, NJ, MPIF.

4. P. K. JONES, K. BUCKLEY-GOLDER, H. DAVID, R. LAWCOCK, D. SARAFINCHAN, R. SHIVANATH, and L. YAO: 'PM '98: world congress on powder metallurgy', Vol. 3, 155; 1998, Shrewsbury, EPMA.

5. A. SALAK: Powder Metall. Int., 1980, 2, 72-75.

6. A. SAlaK, E. DUdrova, and V. MISKOVIC: Powder Metall. Sci. Technol., 1992, 3, 26-35.

7. I. M. V. CANINHA and F. C. RISSO ASSUNCAO: 'PM '90: world congress on powder metallurgy', Vol. 3, 94; 1990, London, The Institute of Metals.

8. G. H. DANNINGER, R. POTTSCHANCHER, G. JANGG, J. SEYRKAMMER. and A. SALAK: 'PM '94: world congress on powder metallurgy', Vol. 2, 879; 1994, Les Ulis, Les Editions de Physique.

9. A. N. KLEIN, R. OBERACKeR, and F. THUMMLER: Powder Metall. Int., 1985, 17, 13-16, 71-74.

10. S. MOCARSKI, D. W. HALL, R. A. CHERNENKOFF, D. A. YEAGER, and C. O. McHUGH: Powder Metall., 1996, 39, 130-137.

11. G. ZAPF, G. HOFFMANN, and K. DAlal: Powder Metall., 1975, 18, 214-236.

12. A. CIAS, S. C. MitChell, and A. S. WRONSKI: PM '98: world congress on powder metallurgy', Vol. 3, 179-184; 1998, Shrewsbury, EPMA

13. A. S. WRONSKI et al.: Final Report on EU Copernicus Contract CIPA CT-94-0108, European Commission, 1998.

14. A. CIAS, S. C. MITCHell, A. WATTS, and A. S. WRONSKI: Powder Metall., 52, 1999, 227-233.

15. S. C. MITCHELl, A. S. WRONSKI, A. CIAS, and M. STOYTCHEV: 'Advances in powder metallurgy and particulate materials', Vol. 3, 7-129; 1999, Princeton, NJ, MPIF.

16. A. ROMANSKI and A. CIAS: Inz. Materialowa, 1998, 4, 1175-1178.

17. M. BANERJEE, G. SCHLIEPER, F. THUMMLER, and G. ZAPF: 'Modern developments in powder metallurgy', Vol. 12, 143; 1981, Princeton, NJ, MPIF.

18. y. MURAMATSU: Trans. Natl Res. Inst. Met., 1984, 26, 37-45.

19. G. D. McADAM: J. Iron Steel Inst., 1951, 168, 346-358.

20. J. R. MOON: Proc. Conf. on 'Deformation and fracture in structural materials', SAS Kosice, 1996, Vol. 1, 61.

21. A. S. WRONSKI and M. M. OLIVEIRA: Inz. Materialowa, 1998, 4, $1123-1130$. 